\title{
Green Spaces and Urban Liveability in Sub-Saharan Africa: Lessons from Bafoussam I, Cameroon
}

\author{
Gideon Samba (Corresponding author) \\ Department of Geography, the University of Bamenda \\ HTTC, Bambili-Bamenda, Cameroon. \\ E-mail:sam_deon@yahoo.fr \\ Reeves Meli Fokeng \\ Department of Geography and Planning, Faculty of Arts \\ The University of Bamenda, Cameroon \\ Julius Tata Nfor \\ Department of Geography and Environmental planning \\ The University of Dschang, Cameroon \\ Roland Chah Ngwaimbi \\ Department of Geography and Planning, Faculty of Arts \\ The University of Bamenda, Cameroon \\ Correspondence be addressed to G. Samba: sam_deon@yahoo.fr
}

Received: December 28, 2021 Accepted: January 25, 2022 Published: February 11, 2022

doi:10.5296/ijgs.v6i1.19390 URL: https://doi.org/10.5296/ijgs.v6i1.19390

\begin{abstract}
Urban green spaces support the development of cities in diverse ways. Considerable work has been done in recent years exploring the value of urban green space for health and wellbeing of urban centres across the world and in Sub-Saharan African countries in particular. This study is designed to examine the contribution of green spaces to city liveability in Bafoussam
\end{abstract}


I Council. Data for the study were obtained through primary and secondary sources using a mixed design method of inquiry which combines both quantitative and qualitative approaches to explore data on urban green spaces in Bafoussam I. Purposive and simple random sampling techniques were used to select households for questionnaire administration. The data engendered were analyzed with descriptive and inferential statistics. The outcomes indicated that green spaces have significantly contributed to the health and wellbeing of the city dwellers in Bafoussam I Council. The main actors responsible for green spaces management in the municipality include government agencies, Bafoussam City Council, Municipal Council, the civil society, and Non-Governmental Organizations. In line with the 2022 African Nations Cup (AFCON) in Cameroon, this city-centre beautification has been stepped up. The Pearson moment Correlation used to test the hypothesis indicated a strong positive correlation at a calculated P-value .001, thus, green spaces have significant effects on the health and wellbeing of urban dwellers in Bafoussam I. The study concluded by emphasizing that stakeholders of green spaces in the municipality need to collaborate to take effective decisions that can be sustainable to ensure protection and equitable management of urban green environment to meet the need of the future generations in line with Sustainable Development Goal (SDG) 11.

Keywords: Open spaces, Greens capes, Liveability, Bafoussam, Cameroon.

\section{Introduction and Study Area}

Globally, there is growing awareness and concern today on the importance of green systems in cities as urban living limits access to nature. These concerns are borne out of the desire to make cities more liveable and sustainable and to achieve these targets; cities must develop good urban green systems. A green system or space could be defined as "any vegetation found in the urban environment, including parks, open spaces, residential gardens, or street trees" (Kabisch, 2013).In many developed countries around the world, the importance of green spaces in improving city liveability can no longer be over-emphasized but in developing countries, the concept of green infrastructure have gained importance only within the last few decades. It is no doubt that the quality and viability of cities depend largely on the design, management and maintenance of urban greenery as well as on open and public spaces that make up an important social constellation and offer a visual representation of urban quality (Sara et al., 2018). There is a renewed interest in public space with a growing belief that while modern societies no longer depend on the town square for basic needs, good public space is required for the social and psychological wellbeing of modern communities. New public green spaces are emerging everyday around the world while old public space typologies are being retrofitted to meet contemporary needs and demands. Good green spaces in modern cities are well-planned, airy, attractive, responsive, democratic and meaningful. However, few comprehensive instruments exist to measure the quality of these green spaces to city liveability especially in less developed countries (Samba et al., 2019; Colding, 2011). It is within this backdrop that this study brings out the contribution of green spaces to city liveability in the city of Bafoussam I, West Region of Cameroon.

An extensive review of literature and empirical works established that pressures in alleviating 
poverty, health and sanitation problems and making available basic human needs are the priorities of many emerging countries (Bolnick et al., 2006; Marcotullio, 2001; Mensah, 2015). This has diverted attention to the management of environmental resources amongst which green spaces (Mensah, 2015; Okech \& Nyadera, 2021). The limited attention given to environmental resources has seen the progressive deterioration in environmental quality as a result of unplanned rapid urbanization that took off since the early 80 's. One of the key remedies to these intolerable environmental conditions was seen in massive park and garden development. Thus, the birth of formal, organized urban green space systems as we witnessed today in our towns and cities. Protecting natural environments like green spaces within physical settings of urban areas has been identified to improve the health and comfort of urban dwellers (Wolch et al., 2014; Cohen et al., 2008; Mensah, 2015; Okech \& Nyadera, 2021).

Historically, human beings have appreciated vegetation to find flavour of life, from some physical and psychological reliance on nature. People love fresh air, natural attraction and landscapes which indicates natural perception and social behaviour (Wuqiang et al., 2012; Gökyer et al., 2012). However, currently, as a result of population growth and urbanization, ecosystems and natural landscape are changing considerably (Barnosky, 2012). Human activities are powering these changes and menacing ecological services that are indispensible to society (Chapin et al., 2011). In like manner, sustainable development has become a key idea to answer a series of environmental, economic and social problems (Rakhshandehroo et al., 2016).

A Growing number of studies on urban green spaces (Rakhshandehroo et al., 2015; Najafpour et al., 2014; Wu, 2014; Hussain, et al., 2014) shows that natural features like gardens, urban parks, forests, and green belts with their particular components (trees, shrubs, water) contribute to quality of life in many ways, providing vital ecosystem services and public benefits in response to rapid land conversion and a urban space with sustainable environmental defence through open green spaces. Urban green space is not only urban parks; it has a vast meaning and can take on many forms, shapes, purposes, and functions. It can vary greatly from community to community, and no single green space example typifies what this term is (Panduro \& Veie, 2013; Swanwick et al., 2003). For the purpose of this study we use the term green space to contain all types of open natural spaces in Bafoussam I urban area.

It is against this background that this paper investigates the contribution of urban green spaces to city liveability in Bafoussam I. Since the year 2000, the government of Cameroon embarked on restructuring Cameroonian towns and cities especially through urban renewal strategies which saw most informal transport sectors re-located at the periphery of towns and cities. The change in status of some towns to City Councils in 2007 as was the case of Bamenda and Bafoussam in the Western Highlands saw major green projects at the limelight geared towards improving the liveability of urban citizens. The development and planning of green spaces came as an exemplary positive environmental externality and plays key role in improving the social, economic, ecological and cultural behaviours of the urban citizens of Bafoussam I and the Bafoussam City Council in general. 


\subsection{Study Area}

Bafoussam I was created by Presidential decree n ${ }^{\circ} 2007 / 117$ of 04/24/2007 of the President of the Republic. Administratively, Bafoussam I Council is located in the Mifi Division, West Region of Cameroon, between the latitude $5^{\circ} 25^{\prime}$ and $5^{\circ} 33^{\prime} 30^{\prime \prime}$ North and Longitude $10^{\circ} 25^{\prime}$ and $10^{\circ} 35^{\prime}$ East of Greenwich Meridian. It covers an area of $91 \mathrm{~km}^{2}$ for the urban area and $73 \mathrm{~km}^{2}$ for the rural area and has approximately 98,339 inhabitants (CDP, 2015). The municipality is limited is bordered in the north by Bafoussam II Council, in the south by the municipality of Pete-Bandjoun, in the east by the Noun River, and in the west by the Bafoussam III Council. Due to demographic pressure, natural flora is almost non-existent in urban areas. However, there are shade trees such as prodocarpus and some ornamental plants; on the not yet built lots and in some premises; there are banana trees, fruit trees and varieties of food crops and market gardens.

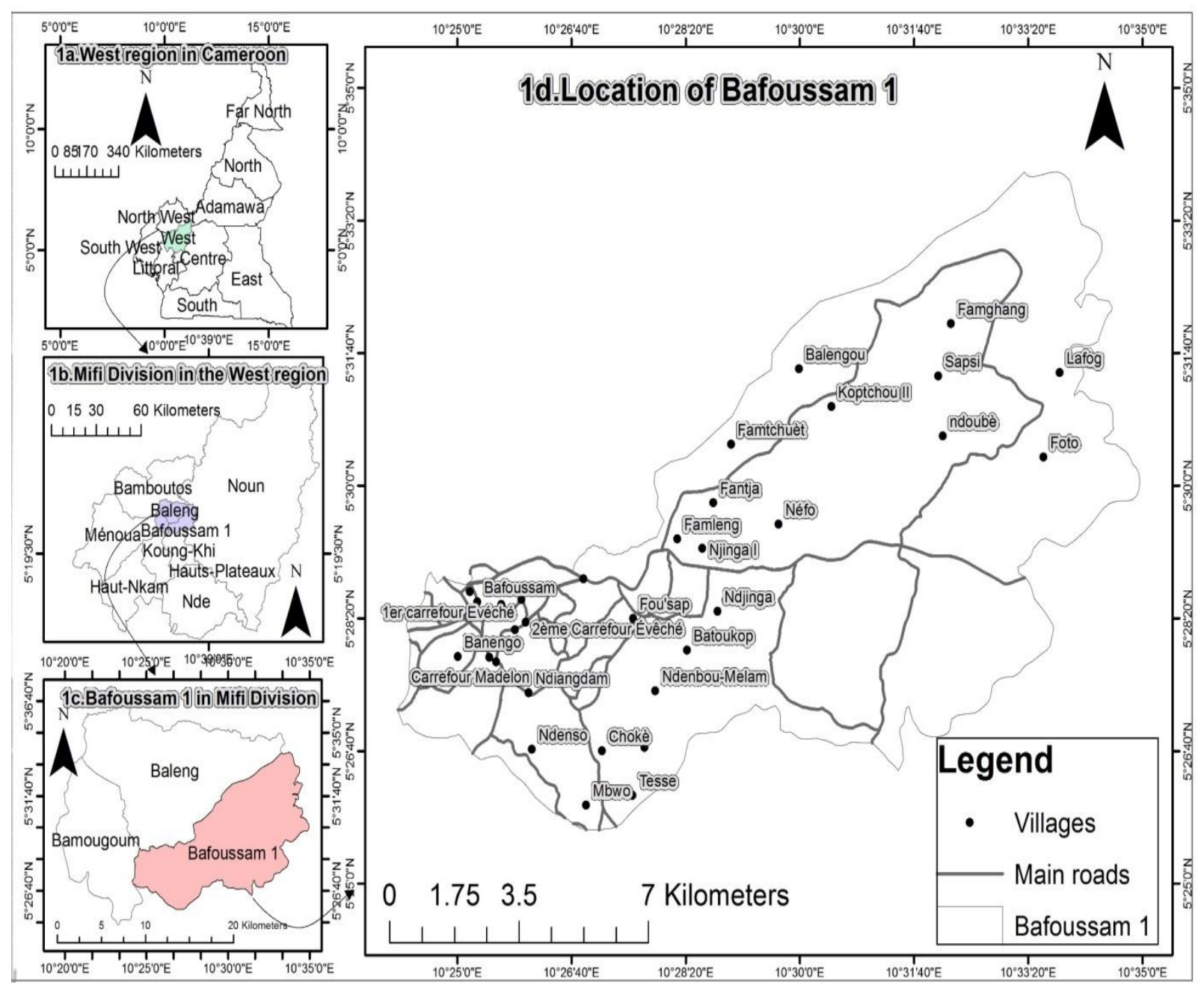

Figure: Location of study area

It should also be noted that the presence of the sacred forest of the chiefdom of Bafoussam where many woody species abound is one of the outstanding green space in the Bafoussam I. 


\section{Methodology}

The study adopts quantitative and qualitative research approaches. The quantitative method involves the use of a survey where semi-structured questionnaires were applied to the sampled population of 156 households derived by using Miller and Brewer (2003) sample determination method at 0.08 marginal error. Field observations on the green spaces sites in the study area were also conducted. For the purpose of in-depth analysis of the results from the quantitative analysis, a further approach, the qualitative method was used including informant interviews with urban greenery stakeholders in Bafoussam I Municipality. The study adopted a purposive and systematic sampling technique. The purposive sampling technique was used to select areas or elements from the population, which met the criteria established. The study area itself was chosen purposively despite the fact there existed other centres where green spaces are found in the Bafoussam City Council. Purposive and simple random sampling techniques were used to select households for questionnaire administration. Data collected was analysed using descriptive and inferential statistics. Descriptive statistics is presented in the form of tables, charts frequencies, percentages, graphs, diagrams, maps and photograph for clarity. Trend significance were verified using Pearson Product Moment Correlation at 0.05 level of significance to verify the hypothesis that urban green spaces contribute significantly to the health and wellbeing of Bafoussam I city dwellers.

\section{Findings and Discussions}

In Bafoussam I, urban green spaces play significant role in people's physical and mental health by providing breathing spaces for people to take time out and refresh from the stresses of modern life. They impact people, the neighbourhoods and quality of life through ecosystem service provision in terms of aesthetics, education and the amelioration of negative aspects of urban life, such as noise reduction, pollution lessening and temperature regulation.

\subsection{Typology of urban green spaces in Bafoussam I municipality}

As can be noted on table 1, forest parks do exist and found at the Bafoussam I traditional palace, recreational parks were mostly identified around administrative quarters and the Kouekong stadium. Forest wetlands were found in two locations at Kouekong, while shrubs were found all over the municipality (Fig. 2). 


\section{Macrothink}

International Journal of Global Sustainability

ISSN 1937-7924 2022, Vol. 6, No. 1

Table 1: Typology of existing urban open spaces in Bafoussam I

\begin{tabular}{|l|l|l|}
\hline SN & $\begin{array}{c}\text { Name of Green infrastructure } \\
\text { inventory }\end{array}$ & \multicolumn{1}{c|}{ Location } \\
\hline 1 & Forest parks & Bafoussam I Chiefdom \\
\hline 2 & Recreation parks & Administrative Quarter, Kouekong \\
\hline 3 & Forest Wetlands & Kouekong \\
\hline 4 & Shrub land & Bafoussam I environs \\
\hline 5 & Hill and rocky environs & Keukon \\
\hline 6 & Lakes and ponds & Found at the outskirts \\
\hline 7 & Private gardens & Zingana hotel, Goden Center hotel, administrative quarter \\
\hline 8 & Street trees & Administrative quarter, Along major streets \\
\hline 9 & Wetlands & Caplamé \\
\hline 10 & Residential greenery & Administrative quarter \\
\hline 11 & Neighbourhood gardens & Eveche roundabout, outskirts \\
\hline
\end{tabular}

There were no lakes and ponds in the study area. In terms of private gardens, resort centres such as Golden Center hotel, Zingana hotel and most administrative residences around were beautified with private green gardens. Street trees and residential greenery around the study area were mostly found within administrative quarters. At the Bishop's House (Eveche) roundabout were some gardens as is the case with neighbouring locations at the outskirt of Bafoussam I municipality. The study revealed that urban greens scape reduced from CBD to the periphery (Fig. 2).

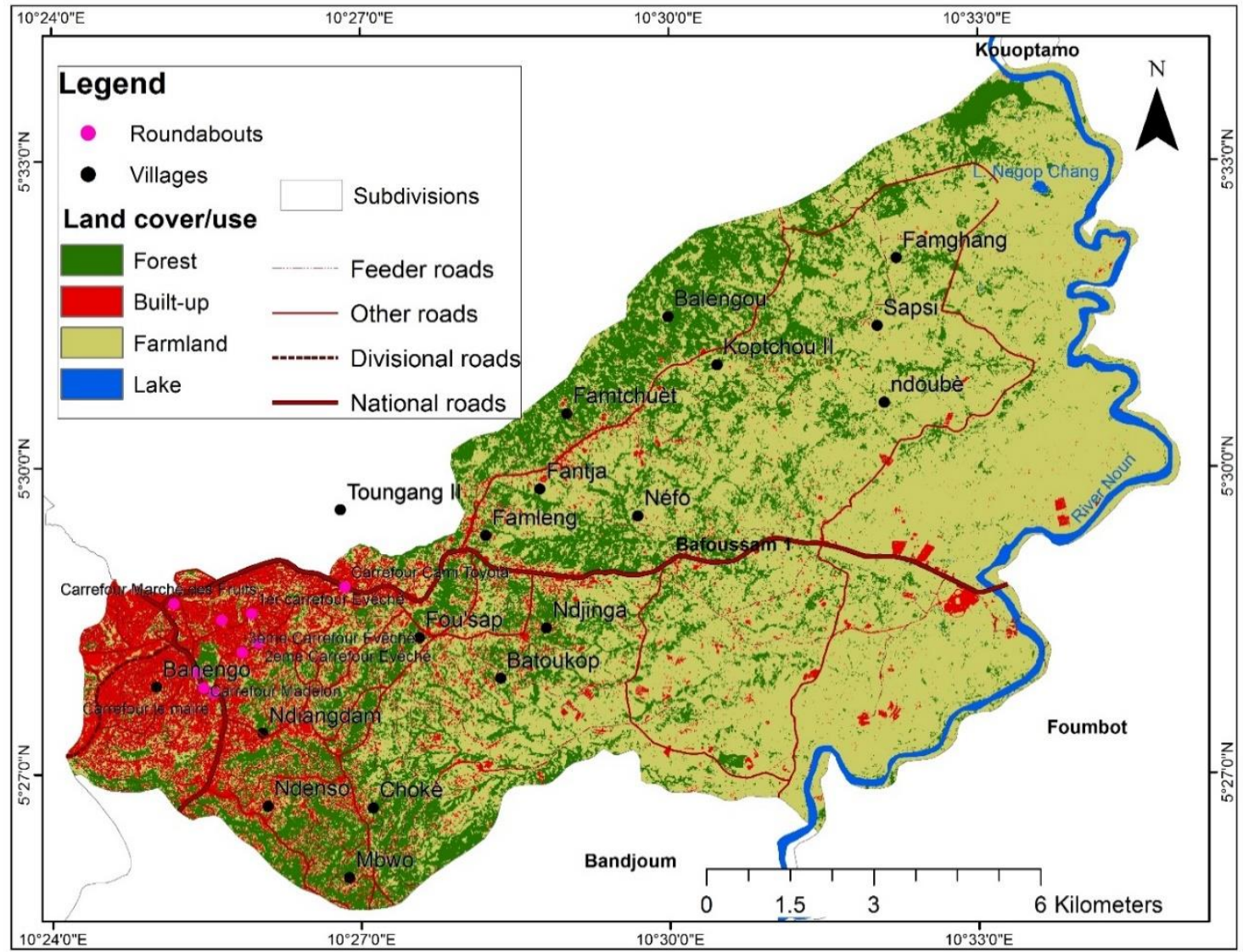

Figure 2: Land use and accessibility in Bafoussam I 


\section{Macrothink}

International Journal of Global Sustainability

ISSN 1937-7924

2022, Vol. 6, No. 1

It is no more news that Modern urban life style is associated with chronic stress, insufficient physical activity and exposure to anthropogenic environmental hazards. Urban green space, such as parks, playgrounds, and residential greenery, can promote mental and physical health and reduce morbidity and mortality in urban centres by providing psychological relaxation and stress alleviation, stimulating social cohesion, supporting physical activity, and reducing exposure to air pollutants, noise and excessive heat.

Table 2: Sample green spaces within Bafoussam I Municipality

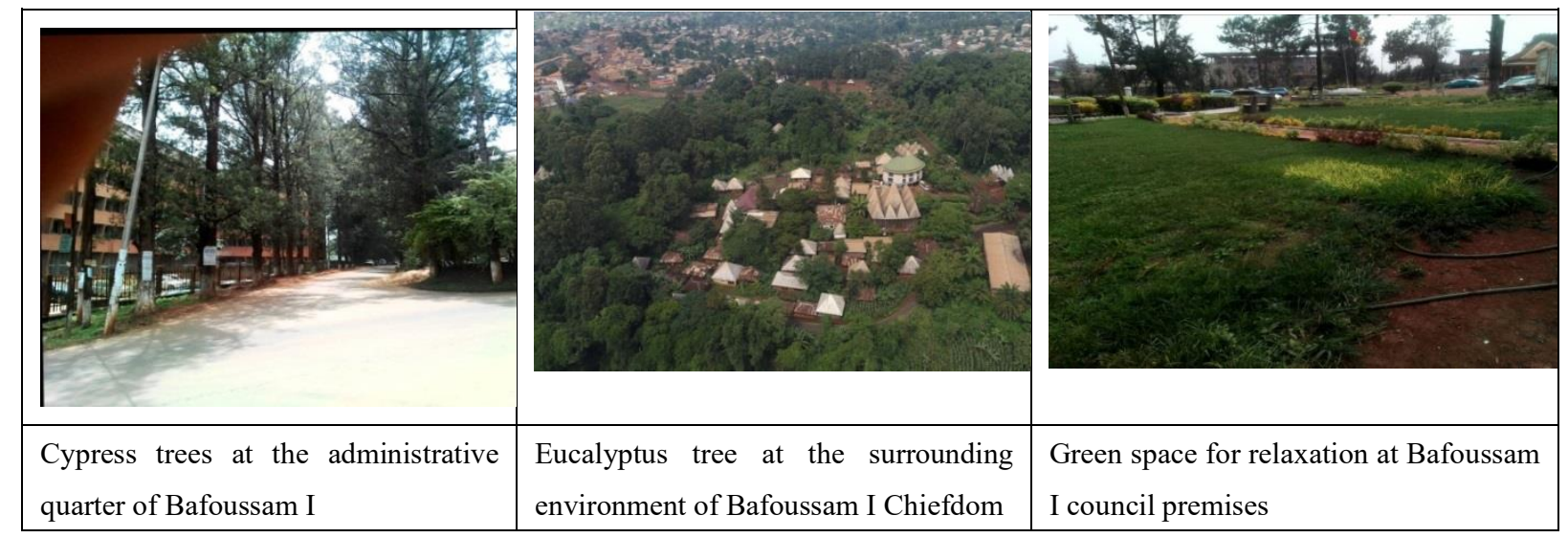

Source: Author's field work photographs, 2021

Scholars such as Haq (2011); Rydin (2010); Baycan-Levent \& Nijkamp, (2009) established that green spaces are important contributors to the realization of sustainable cities which is an essential key indicator of urban liveability.

\subsection{Contribution of green spaces on the health of city dwellers of Bafoussam I}

The opinion of the population was sorted concerning the health and wellbeing with regards to the presence of green spaces. Table 3 revealed overwhelming responses that green spaces have greatly helped in psychological relaxation especially among the aged persons in Bafoussam I. From the descriptive analysis as presented on the table, $92.9 \%$ of the respondents acknowledged this fact, as against 7.1\%. Another major contribution of green spaces was the fact that their presences in Bafoussam I alleviate stress especially as people who are depressed constantly visit these spaces. This was supported by $94.8 \%$ of the respondents. It was also observed that green spaces help stimulate social cohesion, supported by $56.8 \%$; reduce resident's exposure to air pollutants $(80.0 \%)$; reduces noise and excessive heat $(90.4 \%)$; and provide outdoor relaxation to urban citizens in Bafoussam I (97.4\%) respectively. 


\section{Macrothink}

Table 3: Impact of green spaces on health and wellbeing of city dwellers

\begin{tabular}{|c|c|c|c|c|c|c|c|c|c|c|}
\hline \multirow{2}{*}{$\begin{array}{c}\mathbf{V} \\
\mathrm{S} / \mathrm{N}\end{array}$} & \multicolumn{2}{|c|}{$\begin{array}{c}\text { Frequency } \\
(+)\end{array}$} & \multicolumn{6}{|c|}{$\begin{array}{c}\text { Frequency } \\
(-)\end{array}$} & \multirow[t]{2}{*}{$\begin{array}{c}\text { Total } \\
\text { effectives }\end{array}$} & \multirow[t]{2}{*}{$\begin{array}{c}\text { Total } \\
\%\end{array}$} \\
\hline & SA & $\mathbf{A}$ & Total & $\%$ & D & SD & Total & $\%$ & & \\
\hline 1 & 137 & 7 & 144 & $92.9^{*}$ & 7 & 4 & 11 & 7.1 & 155 & 100 \\
\hline 2 & 62 & 84 & 146 & $94.2 *$ & 7 & 2 & 9 & 5.2 & 155 & 100 \\
\hline 3 & 20 & 68 & 88 & $56.8^{*}$ & 40 & 27 & 67 & 43.2 & 155 & 100 \\
\hline 4 & 33 & 91 & 124 & $80.0^{*}$ & 20 & 11 & 31 & 20.0 & 155 & 100 \\
\hline 5 & 109 & 31 & 140 & $90.4^{*}$ & 14 & 1 & 15 & 9.6 & 155 & 100 \\
\hline 6 & 131 & 20 & 151 & $97.4^{*}$ & 4 & 00 & 4 & 2.6 & 155 & 100 \\
\hline 7 & 89 & 34 & 123 & $79.4^{*}$ & 27 & 5 & 32 & 20.6 & 155 & 100 \\
\hline 8 & 38 & 93 & 131 & $84.5^{*}$ & 20 & 4 & 24 & 15.5 & 155 & 100 \\
\hline \multicolumn{11}{|c|}{ Variables used } \\
\hline \multicolumn{11}{|c|}{ 1. Green spaces provide psychological relaxation to the health of citizens } \\
\hline \multicolumn{11}{|c|}{ 2. Green spaces contribute to stress relieve } \\
\hline \multicolumn{11}{|c|}{ 3. It stimulates social cohesion } \\
\hline \multicolumn{11}{|c|}{ 4. It reduces residents exposure to air pollutant } \\
\hline \multicolumn{11}{|c|}{ nd excessive heat harmful to $\mathrm{r}$} \\
\hline \multicolumn{11}{|c|}{ 6. Provide outdoor relaxation to urban citizens } \\
\hline \multicolumn{11}{|c|}{ ysical exercise su } \\
\hline \multicolumn{11}{|c|}{ 8. Provide rest and restitution } \\
\hline
\end{tabular}

Note: $\mathrm{SA}=$ Strongly Agreed; $\mathrm{A}=$ Agreed; $\mathrm{D}=$ Disagreed; $\mathrm{SD}=$ Strongly Disagreed

Source: Author's fieldwork computation, 2021

Also, $79.4 \%$ of the population opined that green spaces contribute in facilitating physical activity exercise such as sport. This group of residents noted that every weekend early in the morning at 5:00 am; they go for sport within and around these public green spaces. This exercise is good for human health and greatly reduces a lot of stress and illnesses. The population equally acknowledged with $84.5 \%$ level of agreement that they use green spaces for rest and restitution.

\subsection{Frequency of usage of green spaces by the population of Bafoussam I}

The population was sampled on how frequent they use green spaces in the Municipality of Bafoussam I. From all indications as presented on figure 2, majority 50.3\% of them regularly use green spaces. 


\section{Macrothink}

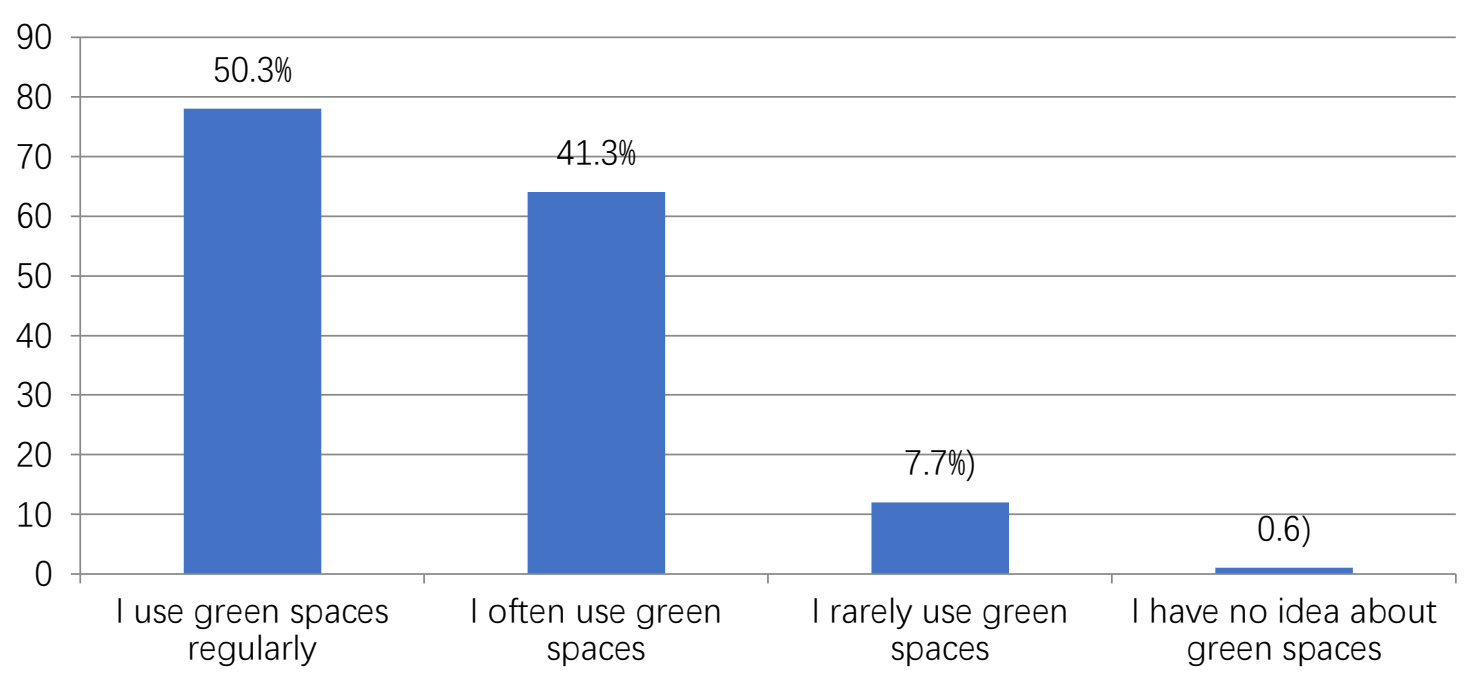

Figure 2: Frequency of usage of green spaces in Bafoussam I

This is to show that green spaces are very valuable in the municipality. $41.3 \%$ indicted that they often use the green spaces, while $7.7 \%$ rarely use the green spaces. From the sample expressions given, it is certain that green spaces play a fundamental role in the health and wellbeing of urban dwellers in Bafoussam I. It also demonstrates the importance of green spaces to city liveability.

\subsection{Verification of hypothesis}

The Decision rule here was that: Reject the null hypothesis and accept the alternative if the critical level of significance (.05) is greater than the calculated p-value otherwise, accept the null hypothesis and reject the alternative.

$\mathrm{H}_{0}$ : urban green spaces do not contribute significantly to the health and wellbeing of Bafoussam I city dwellers

$\mathrm{H}_{1}$ : urban green spaces contribute significantly to the health and wellbeing of Bafoussam I city dwellers

This hypothesis was tested to establish if there exist any significant contribution of urban green spaces to the health and wellbeing of urban dwellers in Bafoussam I. The Pearson moment correlation was considered the best tool in testing the hypothesis to check the relationship between the green spaces and health - wellbeing. From the analysis on table 4, there exist a perfect correlation between green spaces and people's health and wellbeing at a calculated $P$-value of $.000 *$. The correlation coefficient of green spaces stands at 1.000 , while people's health and wellbeing strongly correlate with green spaces with the same calculated P-value $=.000^{*}$. 


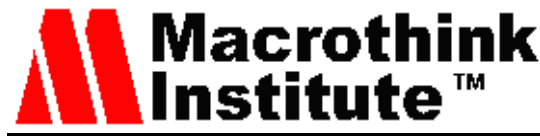

Table 4. Pearson Moment Correlation for green spaces impact on people's health and wellbeing in Bafoussam I

\begin{tabular}{|c|c|c|c|c|}
\hline \multicolumn{3}{|c|}{ Variables control } & \multirow{2}{*}{$\begin{array}{l}\text { Green } \\
\text { spaces } \\
1.000\end{array}$} & \multirow{2}{*}{$\begin{array}{c}\begin{array}{c}\text { People's health and } \\
\text { wellbeing }\end{array} \\
.970 \\
\end{array}$} \\
\hline \multirow{6}{*}{155} & \multirow[t]{3}{*}{ Green spaces } & Correlation & & \\
\hline & & $\begin{array}{c}\text { Sig. } \\
\text { (1tailed) }\end{array}$ & . & $.000^{*}$ \\
\hline & & df1 & 0 & 209 \\
\hline & \multirow{3}{*}{$\begin{array}{l}\text { People's health and } \\
\text { wellbeing }\end{array}$} & Correlation & .970 & 1.000 \\
\hline & & $\begin{array}{c}\text { Sig. } \\
\text { (1tailed) }\end{array}$ & $.000 *$ & . \\
\hline & & $\mathrm{df} 2$ & 605 & 0 \\
\hline
\end{tabular}

Pearson moment correlation coefficient is significant at $0.000^{*}$ alpha level

The calculated P-value in the correlation was $.00^{*}$ which is not up to the targeted significance level .005. With this result, we rejected the null hypothesis that was stated and upheld the alternative. Therefore, the testing the hypothesis confirms the finding that green spaces have had positive significant impacts on the health and wellbeing of the urban dwellers in Bafoussam I consequently contributing significantly to their liveability.

\section{Conclusion}

Available evidence summarized in this paper suggests that potential causal pathways leading to health and wellbeing of urban dwellers in Bafoussam I municipality are the benefits gotten from urban green spaces and includes psychological relaxation and stress reduction, improved social cohesion and psychological attachment to the home area, and enhanced physical activity. The main findings indicated that urban green planning in Bafoussam has significant effect on health and wellbeing of the urban citizens but unplanned urbanization, weak development control, and problem of land are serious conscious issues on the management of green spaces in Bafoussam I council. In recent years, the population of Bafoussam is in constant increased and there are fears that if measures are not put in place to control the population expansion, the remaining few urban green spaces will be completely destroyed. This, therefore, calls for proactive measures by City authorities, town planners, and urban ecologist to put in place measures aimed at building communities' resilience to adapt to these measures thereby accomplishing Sustainable Goal 11which is to "Make cities inclusive, safe, resilient and sustainable".

\section{References}

Baycan-Levent, Tuzin, and Peter Nijkamp (2009)."Urban Green Space Policies: A Comparative Study on Performance and Success Conditions in European Cities." 44th European Congress of the European Regional Science Association Regions and Fiscal Federalism, 25-29 August 2009. Porto, 2004.1-18. 
Bolnick, J., Kayuni, H. M., Mabala, R., McGranahan, G., Mitlin, D., Nkhoma, S., Donk, M. (2006). A pro-poor urban agenda for Africa: Clarifying ecological and Chapin, F. S., Power, M. E., Pickett, S. T. A., Freitag, A., Reynolds, J. A., Jackson, R. B., Power, A. G. (2011). Earth Stewardship: science for action to sustain the human-earth system. Ecosphere, 2(8), $\operatorname{art89.}$

Colding, J. (2011). The Role of Ecosystem Services in Contemporary Urban Planning. In Urban Ecology; Oxford University Press: Oxford, UK, 2011; pp. 228-237.

Cohen, D. A., Inagami, S., \& Finch, B. (2008). The built environment and collective efficacy. Health \& Place, 14(2): 198-208.

Gökyer, B. C. B. and E., Bilgili, B. C., \&Gökyer, E. (2012). Urban Green Space System Planning. In Urban Green Space System Planning, Landscape Planning.

Haq, S. M. A. (2011). Urban green spaces and an integrative approach to sustainable environment. Journal of Environmental Protection, 2: 601-608

Hussain, M. R. M., Tukiman, I., Zen, I. H., \& Shahli, F. M. (2014). The Impact of Landscape Design on House Prices and Values in Residential Development in Urban Areas.

Kabisch, N., Haase, D. (2013). Green spaces of European cities revisited for 1990-2006. Landsc.Urban Plan. 110, 113-122.

Marcotullio, P. J. (2001). Asian urban sustainability in the era of globalization.Habitat

Miller, R. L., \& Brewer, J. D. (2003). A-Z of Social Research.London: Longman.

Najafpour, H., Bigdeli Rad, V., Lamit, H., \& Fitry, S. M. (2014). The Systematic Review on Quality of Life in Urban Neighborhoods. Life Sci J, 11(7), 355-364.

Panduro, T. E., \& Veie, K. L. (2013). Classification and valuation of urban green spaces-A hedonic house price valuation. Landscape and Urban Planning, 120, 119-128.

Rakhshandehroo, M., Mohdyusof, M. J., Mohd, O., \& Tahirholder, M. Y. M. Y. (2015). The social benefits of urban open green spaces: a literature review. Management research and practice, 7(4), 60-71.

Sara Khoshkara, BeritBalforsaand AntoienetteWarrnback. (2018). Planning for green qualities in the densification of suburban Stockholm - opportunities and challenges. Journal of-Environmental-Planning and Management.

https://doi.org/10.1080/09640568.2017.1406342

Samba, G, Ndoki, D, Chianeheng, J.K, \& Nkang, M. J. (2019). Effects of Urbanization on Ecosystem Services in Bamenda III, North West Region- Cameroon. GSJ: Volume 7, Issue 11, ISSN 2320-9186. www.globalscientificjournal.com. Pp. 1539-1551

Swanwick, C., Dunnett, N., \& Woolley, H. (2003). Nature, role and value of green space in towns and cities: an overview. Built Environment, 29(2), 94-106.

Wolch JR, Byrne J, Newell JP. (2014). Urban green space, public health, and environmental 


\section{Macrothink}

justice: the challenge of making cities 'just green enough'. Landscape Urban Plan. 125, 234244.

$\mathrm{Wu}, \mathrm{W}$. (2014). The Concept of Green Infrastructure and Review of Its Research

Wuqiang, Song, \& Wei, (2012). Greenspace in urban neighbourhoods and residents' health: adding quality to quantity. $J$ Epidemiol Community Health, 66(6):e8.

Okech, E. A., \& Nyadera, I. N. (2021). Urban green spaces in the wake of Covid-19 pandemic: reflections from Nairobi, Kenya. GeoJournal, 1-15. Advance online publication. https://doi.org/10.1007/s10708-021-10540-0.

Mensah, C.A. (2015). Sustaining urban green spaces in Africa: a case study of Kumasi Metropolis, Ghana, $\mathrm{PhD}$ thesis, University of Birmingham.

\section{Copyright Disclaimer}

Copyright for this article is retained by the author(s), with first publication rights granted to the journal.

This is an open-access article distributed under the terms and conditions of the Creative Commons Attribution license (http://creativecommons.org/licenses/by/4.0/). 